\title{
Analisis Regresi Data Panel Pengaruh PDRB, Indeks Pembangunan Manusia, dan Tingkat Pengangguran Terbuka terhadap Jumlah Kemiskinan di Kabupaten/Kota di Jawa Barat pada Tahun 2013-2020
}

\author{
Sarah Farida Fitria* \\ Prodi Matematika, Fakultas Matematika dan Ilmu Pengetahuan Alam, \\ Universitas Islam Bandung, Indonesia. \\ *sarahfitria1104@gmail.com

\begin{abstract}
Economic development in Indonesia is currently facing the problem of poverty. One indicator of the success of the implementation of development that can be used as a benchmark at a macro level is economic growth. Regional economic growth can be reflected in changes in Gross Regional Domestic Product in a region. In this development, humans are used as the main source of wealth in a country. This makes the Human Development Index measure the achievement of human development based on a number of basic components of quality of life. Development is carried out to realize community prosperity through economic development in overcoming various development and social problems such as unemployment. Increasing economic growth means that the production of goods/services produced will increase. The best solution in solving the problem of poverty by analyzing the influence of GRDP, HDI, and TPT on the amount of poverty in the Regency/City of West Java Province in 2013-2020. The Panel Data Regression method is used as an analytical tool in the study, by selecting the Fixed Effect Model, it shows that the GRDP, HDI, and TPT variables have a positive and significant effect on the number of poverty in districts/cities in West Java Province.
\end{abstract}

Keywords: Poverty, GRDP, HDI, TPT, Panel Data Regression

\begin{abstract}
Abstrak. Pembangunan ekonomi di Indonesia saat ini sedang dihadapkan pada masalah kemiskinan. Salah satu indikator keberhasilan pelaksanaan pembangunan yang dapat dijadikan tolak ukur secara makro adalah pertumbuhan ekonomi. Pertumbuhan ekonomi daerah dapat dicerminkan dari perubahan Produk Domestik Regional Bruto dalam suatu wilayah. Dalam pembangunan tersebut manusia dijadikan sumber kekayaan utama dalam suatu negara. Hal ini menjadikan Indeks Pembangunan Manusia mengukur capaian pembangunan manusia berbasis sejumlah komponen dasar kualitas hidup. Pembangunan dilakukan untuk mewujudkan kemakmuran masyarakat melalui pengembangan perekonomian dalam mengatasi berbagai permasalahan pembangunan dan sosial kemasyarakatan seperti pengangguran. Pertumbuhan ekonomi yang semakin meningkat berarti produksi barang/jasa yang dihasilkan akan meningkat. Solusi terbaik dalam pemecahan masalah kemiskinan dengan menganalisis pengaruh PDRB, IPM, dan TPT terhadap jumlah kemiskinan di Kabupaten/Kota Provinsi Jawa Barat pada Tahun 2013-2020. Metode Regresi Data Panel digunakan sebagai alat analisis dalam penelitian, dengan memilih Fixed Effect Model menunjukkan variabel PDRB, IPM, dan TPT berpengaruh positif dan signifikan terhadap jumlah kemiskinan Kabupaten/Kota di Provinsi Jawa Barat.
\end{abstract}

Kata Kunci: Kemiskinan, PDRB, IPM, TPT, Regresi Data Panel. 


\section{A. Pendahuluan}

Indonesia merupakan negara berkembang yang masih mempunyai permasalahan mengenai kemiskinan. Secara umum, pada periode 2006 - Maret 2020, tingkat kemiskinan di Indonesia mengalami penurunan, baik dari sisi jumlah penduduk miskin maupun presentase penduduk miskin, perkecualian pada September 2013, Maret 2015, dan Maret 2020. Berdasarkan data dari Badan Pusat Statistik, pada tahun 2020 Jawa Barat menduduki posisi ke-tiga dengan jumlah penduduk miskin terbanyak di Indonesia. Hal ini tercatat masih terdapat sebanyak 3,92 juta penduduk miskin di Jawa Barat [1]. Pemicu dari meningkatnya jumlah penduduk miskin di Jawa Barat ialah pertumbuhan pengeluaran konsumsi rumah tangga pada Produk Domestik Regional Bruto (PDRB) Kuartal I 2020 mengalami pertumbuhan yang melambat, menurunnya sektor pariwisata yang menjadi pendukung meningkatnya pendapatan daerah, serta adanya pandemic Covid-19 yang berdampak pada perubahan perilaku serta aktivitas ekonomi penduduk.

Pertumbuhan ekonomi dijadikan tolak ukur secara makro dalam salah satu indikator keberhasilan pelaksanaan pembangunan. Pertumbuhan ekonomi daerah dapat dicerminkan dari perubahan Produk Domestik Regional Bruto dalam suatu wilayah, baik atas dasar harga berlaku maupun atas dasar harga konstan. Berdasarkan pembukaan UUD 1945 tentang pembangunan nasional Indonesia ialah memajukan kesejahteraan umum. Kesejahteraan umum merupakan kondisi terpenuhinya kebutuhan material, spiritual, dan sosial penduduk negara. Laju penurunan jumlah penduduk miskin dijadikan indikator utama dalam keberhasilan pembangunan ekonomi [2]. Pembangunan nasional adalah salah satu upaya untuk menjadi tujuan masyarakat adil dan makmur. Manusia merupakan kekayaan suatu negara, yang menjadi fokus utama dalam pembangunan adalah peningkatan kualitas manusia.

\section{B. Metodologi Penelitian}

\section{Regresi Data Panel}

Data panel adalah data yang merupakan hasil dari pengamatan pada beberaoa individu atau (unit cross-sectional) yang merupakan masing-masing diamati dalam beberapa periode waktu yang beruntun (unit waktu) [6]. Regresi data panel merupakan sekumpulan teknik untuk memodelkan pengaruh peubah penjelas terhadap peubah respon pada data panel. Secara umum terdapat dua pendekatan yang digunakan dalam menduga model dari data panel yaitu model tanpa pengaruh individu (common effect) dan model dengan pengaruh individu (fixed effect dan random effect). Model tanpa pengaruh individu atau common effect adalah pendugaan yang menggabungkan seluruh data time series dan cross section [7]. Model common effect memberikan nilai $\alpha$ yang sama untuk setiap periode maupun individu. Berikut ini model dari common effect [6] :

$$
Y_{i t}=\alpha+\beta X_{i t}+u_{i t}
$$

$Y_{i t}$ : Pengamatan unit cross-section ke- $i$ dan waktu ke- $t$

$\alpha$ : Intersep model regresi;

$\beta$ : Koefisien kemiringan untuk setiap unit;

$X_{i t}$ : Variabel bebas untuk unit cross-section ke- $i$ dan waktu ke- $t$;

$u_{i t}$ : Nilai error pada unit cross-section ke- $i$ dan waktu ke- $t$.

Model fixed effect merupakan model yang mengasumsikan adanya perbedaan intersep setiap individu. Pada fixed effect model diasumsikan bahwa koefisien slope bernilai konstan tetapi intercept bersifat tidak konstan. Berikut ini model dari fixed effect [8] :

$$
Y_{i t}=\alpha_{i}+\sum_{k=2}^{k} \alpha_{k} D_{k i}+\beta X_{i t}+u_{i t}
$$

$Y_{i t}$ : Pengamatan unit cross-section ke- $i$ dan waktu ke-t;

$D_{k i}$ : Variabel boneka (Variabel dummy);

$\beta$ : Koefisien bebas untuk unit cross-section ke- $i$ dan waktu ke- $t$;

$u_{i t}$ : Nilai error pada unit cross-section ke-i dan waktu ke- $t$. 
Model random effect menunjukkan perbedaan karakteristik-karakteristik individu dan waktu diakomondasikan pada intercept sehingga intercept-nya berubah antar waktu. Berikut ini model dari random effect [9] :

$$
Y_{i t}=\alpha_{i}+\beta X_{i t}+u_{i t}
$$

\section{Pemilihan Model Estimasi Regresi Data Panel}

Uji chow digunakan untuk memilih salah satu model pada regresi data panel, yaitu antara common effect atau fixed effect dengan hipotesis sebagai berikut :

$H_{0}: \alpha_{1}=\alpha_{2}=\cdots=\alpha_{n}=0$ (efek unit cross-section secara keseluruhan tidak berarti)

$H_{1}$ : paling tidak terdapat satu $\alpha_{1} \neq 0 ; i=1,2, \ldots, n$ (efek wilayah berarti)

Statistik uji yang digunakan merupakan uji $\mathrm{F}$, sebagai berikut :

$$
F_{\text {hitung }}=\frac{[R R S S-U R S S] /(n-1)}{U R S S /(n T-n-K)}
$$

RRSS : Restricted Residual Sums of Square yang berasal dari CEM;

URSS: Unrestricted Residual Sums of Square yang berasal dari FEM;

$n \quad$ : Banyaknya data cross-section;

$T \quad$ : Banyaknya data time series;

$K \quad$ : Banyaknya variabel bebas.

Jika nilai $F_{\text {hitung }}>F_{\text {tabel }}$ atau $p-$ value $<\alpha$ maka $H_{0}$ ditolak, yang artinya model yang digunakan adalah Fixed Effect Model [6].

Jika hasil uji Chow $H_{0}$ ditolak maka perlu dilakukan uji hausman untuk menguji modelnya kembali apakah FEM atau REM dengan hipotesis sebagai berikut:

$H_{0}$ : Korelasi $\left(X_{i t}, u_{i t}\right)=0$ (Model yang sesuai yaitu Random Effect Model)

$H_{1}$ : Korelasi $\left(X_{i t}, u_{i t}\right) \neq 0$ (Model yang sesuai yaitu Fixed Effect Model)

$$
i=1,2, \ldots, n ; t=1,2, \ldots, T
$$

Statistik uji yang digunakan sebagai berikut :

$$
W=\left(\hat{\beta}_{F E M}-\hat{\beta}_{R E M}\right)\left[\operatorname{var}\left(\hat{\beta}_{F E M}-\hat{\beta}_{R E M}\right)\right]^{-1}\left(\hat{\beta}_{F E M}-\hat{\beta}_{R E M}\right)
$$

Jika nilai $W>X_{(\alpha, K)}^{2}$ atau nilai $p-$ value $<\alpha$ (tingkat signifikansi) yang ditentukan maka $H_{0}$ ditolak yang artinya model yang sesuai yaitu Fixed Effect Model [6].

\section{UJi Asumsi Model Regresi Data Panel}

1. Uji Normalitas

Pada regresi linear klasik di asumsikan bahwa tiap residual $\left(u_{i}\right)$ didistribusikan secara random dengan $u_{i} \sim N\left(0, \sigma^{2}\right)$. Untuk menguji normalitas residu dapat digunakan uji Jarque-Bera, dengan hipotesis sebagai berikut :

$H_{0} \quad$ : Residual berdistribusi normal.

$H_{1} \quad$ : Residual tidak berdistribusi normal

Statistik uji :

$$
J B=n\left[\frac{S_{k}^{2}}{6}+\frac{(K-3)^{2}}{24}\right]
$$

$n \quad$ : Banyaknya data $S_{k}:$ Skewness (kemencengan);

$K \quad:$ Kurtosis (peruncingan)

$\alpha \quad: 0,05$

$H_{0}$ ditolak jika $J B>x_{(\alpha, 2)}^{2}$ atau $p-$ value $<\alpha$ yang artinya residual tidak berdistribusi normal [10].

2. Uji Multikolinearitas

Uji multikolinearitas digunakan untuk mengetahui ada tidaknya korelasi antar variabel bebas dalam suatu model regresi. Tanda terjadinya multikolinearitas dapat dilihat dari korelasi sederhana yang relatif tinggi antara satu atau lebih pasang variabel bebas. Jika absolute koefisien korelasi berpasangan lebih dari 0,8 maka terjadi multikolinearitas [10].

3. Uji Heteroskedastisitas 
Uji heteroskedastisitas digunakan untuk melihat terdapat ketidaksamaan varians antar residual pengamatan. Model regresi yang baik yaitu yang memiliki kesamaan varians antar residual pengamatan atau disebut homoskedastisitas. Dalam penelitian ini, uji heteroskedastisitas menggunakan Uji Glejser. Uji Glejser dilakukan dengan cara meregresikan variabel-variabel bebas terhadap nilai absolute residualnya. Jika nilai signifikansi variabel bebas lebih dari tingkat signifikansi 5\% maka tidak terjadi masalah heteroskedastisitas dengan persamaan regresi sebagai berikut [9].

4. Uji Autokorelasi

$$
\left|\hat{u}_{i}\right|=\alpha+\beta X_{i}+v_{i}
$$

Autokorelasi yaitu korelasi antara residual satu pengamatan dengan residual pengamatan yang lain. Autokorelasi sering terjadi pada data time series. Pengujian autokorelasi menggunakan statistik uji Durbin-Watson, dengan hipotesis sebagai berikut :

$H_{o}: \rho=0$ (tidak ada autokorelasi positif)

$H_{1}: \rho>0$ (ada autokorelasi positif)

Statistik uji :

$$
D W=\frac{\sum_{i=1}^{n} \sum_{t=2}^{T}\left(\widehat{u}_{i t}-\widehat{u}_{i t-1}\right)^{2}}{\sum_{i=1}^{n} \Sigma_{t=2}^{T} \widehat{u}_{i t}^{2}}
$$

$\hat{u}_{i t} \quad:$ residual pada wilayah ke- $i$ dan waktu ke- $t$.

Kriteria uji :

Jika $D W>d_{U}$, maka tidak terdapat autokorelasi positif.

Jika $D W<d_{L}$, maka terdapat autokorelasi positif.

Jika $d_{L}<D W<d_{U}$, maka tidak dapat ditarik kesimpulan [11].

\section{Pengujian Signifikansi Parameter}

1. Uji Simultan

Uji F digunakan untuk melihat pengaruh secara bersama-sama seluruh variabel bebas dalam model. Secara umum hipotesisnya sebagai berikut :

$H_{0}: \beta_{1}=\beta_{2}=\cdots=\beta_{r}=0$ (Semua variabel bebas berpengaruh signifikan terhadap variabel terikat)

$H_{1}: \beta_{k} \neq 0$ (Paling tidak terdapat satu variabel bebas yang berpengaruh signifikan terhadap variabel terikat), $k=1,2, \ldots, \mathrm{r}$

Kriteria uji :

$H_{0}$ ditolak jika $F_{\text {hitung }}>F_{(k,(n-k), \alpha)}$ atau $p-$ value $<\alpha$ yang artinya paling tidak terdapat satu variabel bebas yang berpengaruh signifikan terhadap variabel terikat [12].

2. Uji Parsial

Uji t digunakan untuk melihat pengaruh secara individu variabel bebas dalam model. Secara umum, hipotesisnya sebagai berikut :

$H_{0}: \beta_{k}=0$ (Variabel bebas tidak berpengaruh signifikan terhadap variabel terikat), $k$ $=1,2, \ldots, r$

$H_{1}: \beta_{k} \neq 0$ (Variabel bebas berpengaruh signifikan terhadap variabel terikat), $k=$ $1,2, \ldots, r$

Kriteria uji :

$H_{0}$ ditolak jika $\left|t_{\text {hitung }}\right|>t_{\frac{\alpha}{2}, n-k-1}$ atau $p-$ value $<\alpha$ yang artinya variabel bebas berpengaruh signifikan terhadap variabel terikat [11].

\section{Hasil Penelitian dan Pembahasan}

Data yang digunakan dalam penelitian ini adalah data tahunan jumlah penduduk miskin, Produk Domestik Regional Bruto, Indeks Pembangunan Manusia, dan Tingkat Penganggura Terbuka di 26 Kabupaten/Kota Provinsi Jawa Barat pada tahun 2013 sampai dengan 2020. 


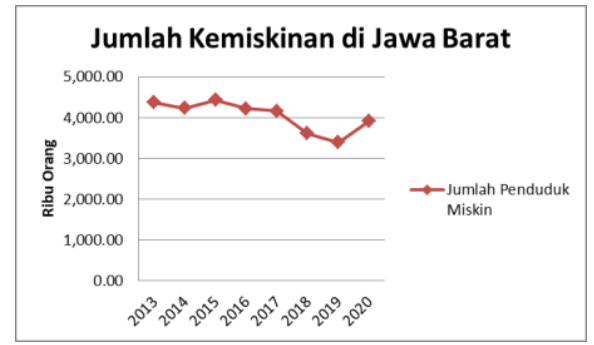

Gambar 1. Jumlah Kemiskinan di Jawa Barat

Pada gambar disamping jumlah penduduk miskin di Jawa Barat dari tahun 2013 sampai dengan 2020 relatif mengalami penurunan. Namun pada tahun 2015 dan 2020 terjadi peningkatan. Sumber data yang digunakan dalam penelitian ini adalah data sekunder, yaitu data yang diperoleh dalam bentuk yang sudah jadi atau sudah dikumpulkan dari sumber lain dan diperoleh dari pihak lain. Metode analisis data yang digunakan dalam penelitian ini adalah analisis regresi data panel dengan metode Ordinary Least Square yang menggunakan data time series dan cross section pada Kabupaten/Kota di Provinsi Jawa Barat pada tahun 2013 sampai dengan 2020.

\section{Pemilihan Model Regresi Data Panel}

Uji chow digunakan untuk menguji model mana yang paling tepat antara common effect model atau fixed effect model dengan cara melihat nilai probabilitas dengan alpha, dengan hipotesis sebagai berikut:

$H_{0}$ : CEM, jika nilai probabilitas F statistiknya $>0,05$

$H_{1}$ : FEM, jika nilai probabilitas $\mathrm{F}$ statistiknya $<0,05$.

Tabel 1. Hasil Uji Chow

\begin{tabular}{lccc}
\hline \multicolumn{1}{c}{ Effect Test } & Statistic & d.f & Prob. \\
\hline Cross-section F & 228,895 & $(25,179)$ & 0,000 \\
Cross-section Chi Square & 727,075 & 25 & 0,000 \\
\hline
\end{tabular}

Data diolah menggunakan Eviews 10

Berdasarkan hasil uji chow pada tabel 1 , nilai probabilitas $\mathrm{F}$ statistik menunjukkan angka 0,000 lebih kecil dari tingkat signifikansi 0,05 maka $H_{0}$ ditolak yang artinya fixed effect model lebih baik atau lebih tepat digunakan dibandingkan common effect model.

Selanjutnya dilakukan pengujian menggunakan uji hausman, uji hausman ini dilakukan untuk menguji model mana yang paling tepat antara fixed effect model dan random effect model dengan melihat hasil nilai probabilitas, dengan hipotesis sebagai berikut :

$H_{0}$ : REM, jika nilai probabilitas Chi-square $>0,05$.

$H_{1}$ : FEM, jika nilai probabilitas Chi-square $<0,05$.

Tabel 2. Hasil Uji Hausman

\begin{tabular}{cccc}
\hline Test Summary & Chi-Sq Statistic & Chi-Sq.d.f & Prob. \\
\hline Cross-Section Random & 47,653316 & 3 & 0,000 \\
\hline
\end{tabular}

Data diolah menggunakan Eviews 10

Berdasarkan hasil uji hausman pada tabel 2 nilai probabilitas Chi-Square menunjukkan angka 0,000 lebih kecil dari tingkat signifikansi 0,05 maka $H_{0}$ ditolak yang artinya fixed effect model lebih baik atau lebih tepat digunakan dibandingkan random effect model. 


\section{Pengujian Asumsi Klasik Regresi Data Panel}

Pengujian asumsi normalitas dari residual menggunakan uji Jarque-Bera. Dengan $H_{0}$ yaitu residual berdistribusi normal jika nilai probability > 0,05 dan $H_{1}$ yaitu residual tidak berdistribusi normal jika nilai probability $<0,05$. Berdasarkan gambar diatas terlihat bahwa hasil uji normalitas residual diatas adalah nilai Jarque-Bera Probability sebesar 1,233 dengan $p$-value sebesar 0,539 dimana $>0,05$ sehingga $H_{0}$ diterima yang artinya residual berdistribusi normal.

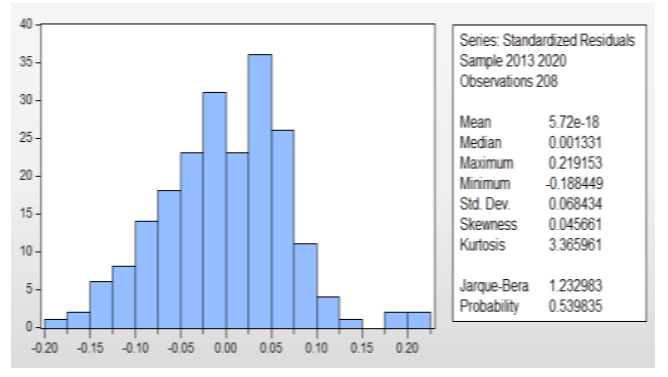

Gambar 2. Series Standardzed Residuals

Data diolah menggunakan Eviews 10

Tabel 3. Uji Multikolinieritas

\begin{tabular}{cccc}
\hline & $X_{1}$ & $X_{2}$ & $X_{3}$ \\
\hline$X_{1}$ & 1 & 0,168 & 0,225 \\
$X_{2}$ & 0,168 & 1 & 0,104 \\
$X_{3}$ & 0,225 & 0,104 & 1 \\
\hline
\end{tabular}

Tujuan dari uji multikolinearitas ialah untuk menguji apakah suatu metode regresi terdapat korelasi antar variabel independen. Berdasarkan

tabel diketahui nilai absolute koefisien korelasi tidak ada yang melebihi 0,8 maka dapat disimpulkan tidak terjadi multikolinearitas antar variabel bebas.

Tabel 4. Uji Heteroskedastisitas

\begin{tabular}{ccccc}
\hline Variable & Coefficient & Std. Error & t-Statistic & Prob. \\
\hline $\mathrm{C}$ & $-0,0001$ & 0,0412 & $-0,0035$ & 0,9972 \\
$X_{1}$ & $-6,4400$ & 5,4600 & $-0,1180$ & 0,9062 \\
$X_{2}$ & 0,0011 & 0,0006 & 1,8976 & 0,0592 \\
$X_{3}$ & $-0,0002$ & 0,0014 & $-1,9006$ & 0,0588 \\
\hline
\end{tabular}

Tujuan dari uji heteroskedastisitas adalah untuk menguji apakah varian konstan atau tidak konstan. Model regresi yang baik yaitu yang memiliki kesamaan varians dari residu antar pengamatan. $H_{0}$ nya yaitu tidak terjadi heteroskedastisitas jika nilai probability $>$ nilai signifikansi 0,05 dan $H_{1}$ yaitu terjadi heteroskedastisitas jika nilai probability $<0,05$. Berdasarkan tabel diatas, nilai probabilitas masing-masing variabel lebih besar dari tingkat signifikansi 0,05 maka $H_{0}$ tidak ditolak yang artinya tidak terjadi heteroskedastisitas. Dengan kata lain model memiliki kesamaan varians residu antar pengamatan.

Tabel 5. Uji Autokorelasi

\begin{tabular}{|c|c|c|c|c|}
\hline Variable & Coefficient & Std. Error & t-Statistic & Prob. \\
\hline C & 16,591 & 1,630 & 10,175 & 0,000 \\
\hline
\end{tabular}




\begin{tabular}{|c|c|c|c|c|}
\hline$X_{1}$ & $-0,248$ & 0,097 & $-2,552$ & 0,012 \\
\hline$X_{2}$ & $-2,228$ & 0,579 & $-3,843$ & 0,000 \\
\hline$X_{3}$ & 0,093 & 0,034 & 2,754 & 0,007 \\
\hline R-Square & 0,994 & \multicolumn{2}{|c|}{ Prob(F-Statistic) } & 0,000 \\
\hline Adjusted R-Square & 0,993 & \multicolumn{2}{|c|}{ S.D. dependent var } & 0,854 \\
\hline F-Statistic & 988,509 & \multicolumn{2}{|c|}{ Durbin-Watson stat } & 1,314 \\
\hline
\end{tabular}

Berdasarkan tabel 5 pada penelitian ini uji autokorelasi menggunakan uji DurbinWatson untuk mengetahui adanya korelasi antara residual, dengan $H_{0}$ yaitu tidak terdapat autokorelasi positif dan $H_{1}$ yaitu terdapat autokorelasi positif. Diketahui nilai durbin-watson sebesar 1,314. berdasarkan tabel durbin-watson dengan $n=208$ dan $k=4$, diperoleh nilai $d_{L}=$ 1,733 dan $d_{u}=1,795$. Karena nilai Durbin Watson lebih kecil dari $d_{L}$ sesuai dengan kriteria uji pada sub bab 2.8.4 maka $H_{0}$ ditolak yang artinya terdapat autokorelasi positif antar residual.

\section{Pengujian Signifikansi Parameter}

Tabel 6. Uji F

\begin{tabular}{|c|c|c|c|}
\hline Variable & Coefficient & Std. Error & Prob. \\
\hline $\mathrm{C}$ & 16,591 & 1,630 & 0,000 \\
\hline$X_{1}$ & $-0,248$ & 0,097 & 0,012 \\
\hline$X_{2}$ & $-2,228$ & 0,579 & 0,000 \\
\hline$X_{3}$ & 0,093 & 0,034 & 0,007 \\
\hline R-Square & 0,994 & $\begin{array}{c}\text { Prob } \\
\text { (F-Statistic) }\end{array}$ & 0,000 \\
\hline Adjusted R-Square & 0,993 & S.D. dependent & 0,854 \\
\hline F-Statistic & 988,509 & Durbin-Watson stat & 1,314 \\
\hline
\end{tabular}

Uji F ini bertujuan untuk melihat pengaruh variabel bebas secara bersama-sama terhadap variabel terikat. Berdasarkan tabel disamping nilai R-Square bernilai 0,994 menunjukkan besarnya pengaruh atau kemampuan PDRB, IPM, dan TPT secara simultan dalam menjelaskan jumlah kemiskinan, artinya sebesar 99,45\% PDRB, IPM dan TPT berpengaruh kuat terhadap jumlah kemiskinan.

Tabel 7. Uji T

\begin{tabular}{|c|c|c|}
\hline Variabel & t-statistic & Prob. \\
\hline $\mathrm{C}$ & 10,175 & 0,000 \\
\hline$X_{1}$ & $-2,552$ & 0,012 \\
\hline$X_{2}$ & $-3,843$ & 0,000 \\
\hline$X_{3}$ & 2,754 & 0,007 \\
\hline
\end{tabular}

Pada tabel 3.12 diketahui semua variabel bebas nilai probabilitasnya lebih kecil dari 
tingkat signifikansi 0,05 maka $H_{0}$ ditolak yang artinya variabel independen PDRB $\left(X_{1}\right)$, IPM $\left(X_{2}\right)$, dan TPT $\left(X_{3}\right)$ secara individu atau parsial berpengaruh signifikan terhadap variabel dependen jumlah kemiskinan.

\section{Model Akhir Regresi Data Panel}

Berdasarkan Uji Chow dan Uji Hausman estimasi model regresi data panel yang tepat untuk jumlah kemiskinan di Kabupaten/Kota Provinsi Jawa Barat pada tahun 2013 sampai dengan 2020 ialah Fixed Effect Model. Karena FEM adalah model terbaik maka setiap wilayah memiliki nilai koefisien intersep yang berbeda seperti pada tabel dibawah. Jadi diperoleh model jumlah kemiskinan di Kabupaten/Kota Provinsi Jawa Barat sebagai berikut:

Dengan :

$$
\widehat{J K}_{i t}=\hat{\alpha}_{i}-0,248 P D R B_{i t}-2,228 I P M_{i t}+0,093 T P T_{i t}
$$

$\widehat{J K}_{i t} \quad$ : Estimasi Jumlah Kemiskinan wilayah ke-i dan tahun ke-t;

$\hat{\alpha}_{i} \quad$ : Estimasi intersep wilayah ke- $i$;

$P D R B_{i t}$ : Produk Domestik Regional Bruto wilayah ke- $i$ dan tahun ke-t;

$I P M_{i t}$ : Indeks Pembangunan Manusia wilayah ke- $i$ dan tahun ke- $t$;

$T P T_{i t}$ : Tingkat Pengangguran Terbuka wilayah ke- $i$ dan tahun ke- $t$.

Dari model FEM diatas dapat diartikan bahwa :

1. $P D R B_{i t}=-0,248$, artinya dengan asumsi IPM dan TPT wilayah ke- $i$ dan tahun ke- $t$ bernilai tetap/konstan, maka setiap peningkatan PDRB sebesar $1 \%$ akan menurunkan Jumlah kemiskinan sebesar $0,248 \%$.

2. $I P M_{i t}=-2,228$, artinya dengan asumsi PDRB dan TPT wilayah ke- $i$ dan tahun ke- $t$ bernilai tetap/konstan, maka setiap peningkatan IPM sebesar $1 \%$ akan menurunkan Jumlah kemiskinan sebesar 2,228\%.

3. $T P T_{i t}=0,093$, artinya dengan asumsi PDRB dan IPM wilayah ke- $i$ dan tahun ke- $t$ bernilai tetap/konstan, maka setiap peningkatan TPT sebesar $1 \%$ akan meningkatkan Jumlah kemiskinan sebesar 0,093\%.

Kedua variabel independen yaitu PDRB dan IPM bernilai negatif dan berpengaruh signifikan terhadap jumlah kemiskinan Kabupaten/Kota di Provinsi Jawa Barat. Sedangkan variabel independen TPT bernilai positif dan berpengaruh signifikan terhadap jumlah kemiskinan Kabupaten/Kota di Provinsi Jawa Barat. Variabel Produk Domestik Regional Bruto dan Indeks Pembangunan Manusia berpengaruh negatif dan signifikan terhadap jumlah kemiskinan di Kabupaten/Kota Provinsi Jawa Barat, hal ini diartikan bahwa semakin tinggi Produk Domestik Regional Bruto dan Indeks Pembangunan Manusia maka jumlah kemiskinan di Kabupaten/Kota Provinsi Jawa Barat akan menurun. Variabel Tingkat Pengangguran Terbuka berpengaruh positif dan signifikan terhadap jumlah kemiskinan di Kabupaten/Kota Provinsi Jawa Barat, hal ini diartikan bahwa ketika Tingkat Pengangguran Terbuka di Kabupaten/Kota Provinsi Jawa Barat mengalami peningkatan maka jumlah kemiskinan di Kabupaten/Kota Provinsi Jawa Barat akan meningkat.Dengan koefisien determinasi sebesar 99,45\% artinya variabel Produk Domestik Regional Bruto, Indeks Pembangunan Manusia, dan Tingkat Pengangguran Terbuka dapat menjelaskan Jumlah Penduduk Miskin Kabupaten/Kota di Provinsi Jawa Barat sebesar 99,45\% dan 0,55\% dijelaskan oleh variabel lain yang tidak masuk model.

Tabel 8. Koefisien Regresi

\begin{tabular}{|c|c|c|c|c|c|}
\hline$i$ & Kab/Kota & $\hat{\alpha}_{i}$ & $i$ & Kab/Kota & $\hat{\alpha}_{i}$ \\
\hline 1 & Bogor & 18,251 & 14 & Purwakarta & 16,242 \\
\hline 2 & Sukabumi & 16,985 & 15 & Karawang & 17,516 \\
\hline 3 & Cianjur & 17,060 & 16 & Bekasi & 17,469 \\
\hline
\end{tabular}




\begin{tabular}{|c|c|c|c|c|c|}
\hline 4 & Bandung & 17,649 & 17 & Bandung Barat & 16,892 \\
\hline 5 & Garut & 17,317 & 18 & Kota Bogor & 16,235 \\
\hline 6 & Tasikmalaya & 16,777 & 19 & Kota Sukabumi & 14,775 \\
\hline 7 & Ciamis & 16,321 & 20 & Kota Bandung & 17,176 \\
\hline 8 & Kuningan & 16,489 & 21 & Kota Cirebon & 15,140 \\
\hline 9 & Cirebon & 17,294 & 22 & Kota Bekasi & 17,173 \\
\hline 10 & Majalengka & 16,592 & 23 & Kota Depok & 16,117 \\
\hline 11 & Sumedang & 16,509 & 24 & Kota Cimahi & 15,372 \\
\hline 12 & Indramayu & 17,244 & 25 & Kota Tasikmalaya & 16,239 \\
\hline 13 & Subang & 16,774 & 26 & Kota Banjar & 13,741 \\
\hline
\end{tabular}

Persamaan regresi data panel memiliki dua koefisien utama yaitu koefisien konstanta (intercept) dan koefisien regresi dari masing-masing variabel. Dalam hal ini besaran konstanta yang dihasilkan berdasarkan tabel 8 menunjukkan ketika variabel PDRB, IPM, dan TPT pada Kota Banjar bernilai tetap/konstan maka jumlah kemiskinan sebesar 13,741.

\section{Kesimpulan}

Berdasarkan hasil penerapan metode regresi data panel untuk jumlah kemiskinan di Kabupaten/Kota Provinsi Jawa Barat pada tahun 2013 sampai dengan 2020, model regresi data panel yang baik digunakan terhadap Produk Domestik Regional Bruto, Indeks Pembangunan Manusia, dan Tingkat Pengangguran Terbuka ialah Fixed Effect Model, setiap variabel Produk Domestik Regional Bruto, Indeks Pembangunan Manusia, dan Tingkat Pengangguran Terbuka secara simultan maupun parsial berpengaruh terhadap jumlah kemiskinan di Kabupaten/Kota Provinsi Jawa Barat pada tahun 2013 sampai dengan 2020.

\section{Acknowledge}

Penelitian ini dapat dilaksanakan dengan baik berkat bantuan dari berbagai pihak, untuk itu peneliti mengucapkan terimakasih kepada :

1. Bapak Abdul Kudus, S.Si., M.Si., Ph.D selaku Dekan Fakultas Matematika dan Ilmu Pengetahuan Alam

2. Bapak DR. Didi Suhaedi, S.Si., M.Kom. selaku ketua Program Studi Matematika dan Pembimbing 1 yang telah membimbing dalam penyelesaian skripsi ini.

3. Ibu Yurika Permanasari, S.Si., M.Kom. selaku dosen pembimbing yang telah membimbing dalam penyelesaian skripsi ini.

4. Bapak Gani Gunawan, S.Si., M.Si. selaku wali dosen yang telah memberikan pengarahan serta dukungan kepada penulis selama menjalankan perkuliahan.

\section{Daftar Pustaka}

[1] Badan Pusat Statistik. 2020. Berita Resmi Statistik, September. BPS RI

[2] Andykha. R, dkk. 2018. Analisis Pengaruh PDRB, Tingkat Pengangguran dan IPM Terhadap Tingkat Kemiskinan di Provinsi Jawa Tengah, Media Ekonomi, Vol. 33 No. 2

[3] World Bank. 2006. Making the New Indonesia Work for the Poor.

[4] Badan Pusat Statistik. 2020. Provinsi Jawa Barat Dalam Angka. BPS RI

[5] Susanti, S. 2013. Pengaruh Produk Domestik Regional Bruto, Pengangguran dan Indeks 
128 | Sarah Farida Fitria, et al.

Pembangunan Manusia terhadap Kemiskinan di Jawa Barat dengan Menggunakan Analisis Data Panel. Jurnal Matematika Ingratif, Vol. 9 No. 1

[6] Baltagi, B.H. 2005. Econometrics Analysis of Panel Data. Edisi 3. Chicester, England: John Wiley \& Sons Ltd.

[7] Sembodo, Heri. 2013. Pemodelan Regresi pada Pendapatan Asli Daerah (PAD) dan Dana Alokasi Umum (DAU) Terhadap Belanja Daerah. Jurnal Mahasiswa Statistik, (14):297-300.

[8] Gujarati, D. N. 2004. Basic Econometrics (4 $\left.{ }^{\text {th }} e d\right)$. New York: The McGraw-Hill Companies.

[9] Nachrowi, D. N \& H. Usman. 2006. Pendekatan Populer dan Praktis Ekonometrika untuk Analisis Ekonomi dan Keuangan. Jakarta: Lembaga Penerbit UI.

[10] Ghozali, I. 2016. Aplikasi Analisis Multivariate. Edisi 8. Semarang: Badan Penerbit Universitas Diponegoro.

[11] Damodar N., Gujarati dan Dawn C. Porter. 2009. Basic Econometrics $5^{\text {th }}$ Edition. McGrawHill: New York.

[12] Sahid, 2004. Pengantar Komputasi Numerik. Yogyakarta: FMIPA UNY 